\title{
2-Amino-3-ketobutyrate CoA ligase of Escherichia coli: stoichiometry of pyridoxal phosphate binding and location of the pyridoxyllysine peptide in the primary structure of the enzyme
}

\author{
Jagat J. Mukherjee and Eugene E. Dekker \\ Department of Biological Chemistry, The University of Michigan, Ann Arbor, MI (U.S.A.)
}

(Received 15 June 1989)

Key words: Threonine metabolism; 2-Amino-3-ketobutyrate CoA ligase; Pyridoxal phosphate; Pyridoxyllysine peptide; (E. coli)

\begin{abstract}
Pure 2-amino-3-ketobutyrate CoA ligase from Escherichia coli, which catalyzes the cleavage/condensation reaction between 2-amino-3-ketobutyrate (the presumed product of the L-threonine dehydrogenase-catalyzed reaction) and glycine + acetyl-CoA, is a dimeric enzyme $\left(M_{\mathrm{r}}=\mathbf{8 4 0 0 0}\right)$ that requires pyridoxal 5 -phosphate as coenzyme for catalytic activity. Reduction of the hololigase with tritiated $\mathrm{NaBH}_{4}$ yields an inactive, radioactive enzyme adduct; acid hydrolysis of this adduct allowed for the isolation and identification of $e-N$-pyridoxyllysine. Quantitative determinations established that 2 mol of pyridoxal 5 '-phosphate are bound per mol of dimeric enzyme. After the inactive, tritiated enzyme adduct was digested with trypsin, a single radioactive peptide containing 23 amino acids was isolated and found to have the following primary structure: Val-Asp-Ile-Ile-Thr-Gly-Thr-Leu-Gly-Lys-Ala-Leu-Gly-Gly-Ala-Ser-Gly-Gly-Tyr-ThrAla-Ala-Arg (where * = the lysine residue in azomethine linkage with pyridoxal 5 '-phosphate). This peptide corresponds to residues $235-257$ in the intact protein; 10 residues around the lysine residue have a high level of homology with a segment of the primary structure of 5-aminolevulinate synthase from chicken liver.
\end{abstract}

\section{Introduction}

The pathway initiated by L-threonine dehydrogenase (EC 1.1.1.103) has recently been shown to be the primary route for threonine utilization in both eukaryotes $[1,2]$ and prokaryotes $[3,4]$; threonine dehydrogenase catalyzes the conversion of $\mathrm{L}$-threonine to the putative unstable intermediate, 2-amino-3-ketobutyrate, which has the potential of spontaneously decarboxylating liberating aminoacetone plus $\mathrm{CO}_{2}$. 2-Amino-3-ketobutyrate CoA ligase (2-amino-3-ketobutyrate $+\mathrm{CoA} \rightleftharpoons$ acetyl$\mathrm{CoA}+$ glycine; 2-amino-3-oxobutanoate glycine-lyase (CoA-acetylating), EC 2.3.1.29) catalyzes the second step in this pathway; the glycine so formed can be utilized by Escherichia coli in a highly efficient alternate pathway for serine biosynthesis [5].

\footnotetext{
Abbreviations: HPLC, high-performance liquid chromatography; PTH, phenylthiohydantoin; TFA, trifluoroacetic acid; TPCK, L-1tosylamido-2-phenylethyl chloromethyl ketone; PTC, phenylthiocarbomoyl; Hepes, 4-(2-hydroxyethyl)-1-piperazineethanesulphonic acid.

Correspondence: E.E. Dekker, Department of Biological Chemistry/0606, The University of Michigan Medical School, 1301 Catherine Rd., Ann Arbor, MI 48109-0606, U.S.A.
}

Although it has been detected in a wide variety of cells/tissues [6-10], 2-amino-3-ketobutyrate ligase has so far only recently been obtained in homogeneous form from extracts of beef liver mitochondria [11] and Escherichia coli K-12 [12]. The E. coli enzyme has a molecular weight of approx. 84000 and consists of two apparently identical subunits; it is a pyridoxal 5'-phosphate-dependent enzyme and is strictly specific for glycine [12]. Furthermore, the complete amino acid sequence of $E$. coli 2-amino-3-ketobutyrate ligase has been inferred via DNA sequencing of a 3.7 kilobase chromosomal fragment [13].

In efforts to elucidate how this dehydrogenase/ligase enzyme system is tightly coupled or may even form a catalytic complex that allows for efficient passage of the unstable 2-amino-3-ketobutyrate to the ligase so that it is cleaved rather than spontaneously decarboxylated, we are attempting in one line of endeavor to establish structure-function interrelationships for each pure protein. Pyridoxal 5'-phosphate certainly participates in the catalytically active center of the ligase, so we report here the stoichiometry of coenzyme binding as well as the amino acid sequence of the pyridoxyllysine peptide and its location in the primary structure of the enzyme. 
Materials and Methods

\section{Chemicals and enzymes}

HPLC-grade acetonitrile was obtained from Burdick \& Jackson Laboratories. $\mathrm{NaB}^{3} \mathrm{H}_{4}(22.2 \mathrm{Ci} / \mathrm{mmol})$ was purchased from Amersham International. The following materials were obtained from the companies indicated: Avicel thin-layer plates $(250 \mu)$ from Analtech; pyridoxal $\cdot \mathrm{HCl}$ and PTH-amino acid standards from Sigma Chemical Co.; $\alpha-N$-carbobenzoxylysine from Cyclo Chemical Co.; TFA (redistilled before use) from J.T. Baker Chemical Co.; TPCK-trypsin from Worthington Biochemicals Corp. All other chemicals were of the highest purity commercially available and all water used was deionized and then glass-distilled.

$\varepsilon-N$-Pyridoxyllysine was synthesized by the procedure of Forrey et al. [14]; all steps were carried out as much as possible in the absence of light. The final product was purified by crystallization from aqueous ethanol. Approx. a $50 \%$ yield of pure product was obtained.

Analytical peptide maps were obtained and the separation of PTH-amino acids was accomplished with the use of a Waters Associates (Milford, MA) gradient HPLC-system consisting of two M510 pumps, a Model 680 gradient controller, a U6K injector, a Model 441 fixed wavelength detector, and a Hewlett-Packard 3390A integrator.

2-Amino-3-ketobutyrate ligase was purified from extracts of mutant $E$. coli SBD-76 cells as reported earlier [12]; homogeneity of all samples was established by polyacrylamide gel electrophoresis. The specific activity of enzyme preparations used in these studies was in the range of 2.5-2.8 units per $\mathrm{mg}$ of protein as determined by Assay I [12]. Molar enzyme concentrations are based on the ligase having a molecular weight of 84000 and consisting of two apparently identical subunits [12]. Carboxypeptidase $\mathrm{Y}$ was purchased from Sigma Chemical Co.

\section{Formation of the tritiated pyridoxal phosphate-enzyme adduct}

The hololigase $(0.4 \mu \mathrm{mol})$, in $50 \mathrm{mM}$ potassium phosphate buffer ( $\mathrm{pH} 7.2)$ containing $0.01 \%(\mathrm{v} / \mathrm{v})$ octyl alcohol, was first warmed slowly to room temperature. $\mathrm{NaB}^{3} \mathrm{H}_{4}(1 \mathrm{mCi})$ was then added with thorough stirring followed by $2.5 \mu \mathrm{mol}$ of $\mathrm{NaBH}_{4}$ and the $\mathrm{pH}$ of the mixture immediately adjusted to 6.0 with $1 \mathrm{M}$ acetic acid. The reductive reaction was allowed to proceed for 10 min during which time the $\mathrm{pH}$ of the solution was maintained at 6.0. Addition of $\mathrm{NaBH}_{4}(250: 1 \mathrm{~mol}$ ratio, $\mathrm{NaBH}_{4}$ /enzyme subunit) followed by acetic acid was repeated three more times over a period of $30 \mathrm{~min}$. Thereafter, reduced enzyme adduct was dialyzed at $4^{\circ} \mathrm{C}$ against $50 \mathrm{mM}$ potassium phosphate buffer ( $\mathrm{pH} 6.5$ ) until the dialysis buffer contained only the background level of radioactivity. The pyridoxal phosphate-ligase adduct so prepared was completely inactive catalytically and showed the expected absorption maximum at 333 $\mathrm{nm}$; no absorption was evident at $400-430 \mathrm{~nm}$, indicating the absence of any unreduced azomethine linkage [12]. The content of protein in solution was determined by the method of Lowry et al. [15] and the level of radioactivity by liquid scintillation counting using a Packard Model 3330 Spectrometer.

\section{Thiol alkylation of the reduced enzyme adduct}

The solution containing the reduced pyridoxal phosphate-ligase adduct was made $6 \mathrm{M}$ with respect to guanidine $\cdot \mathrm{HCl}$; the solution $\mathrm{pH}$ was then adjusted to 8.5 with triethylamine and this mixture allowed to stand for $30 \mathrm{~min}$ under argon. A 5 -fold molar excess (with respect to protein thiols) of dithiothreitol was then added, the $\mathrm{pH}$ of the solution was adjusted to 8.5 with triethylamine, and reduction was allowed to proceed for $4 \mathrm{~h}$ under argon. A 10-fold molar excess (with respect to protein thiols) of solid iodoacetamide was finally added and the $\mathrm{pH}$ of the solution was again adjusted to 8.5 with triethylamine. After alkylation occurred in the dark for $3 \mathrm{~h}$, the reaction was terminated by adding $\beta$-mercaptoethanol (5:1 mol ratio, $\beta$-mercaptoethanol/ iodoacetamide). The alkylated enzyme adduct was dialyzed overnight in the dark at $4^{\circ} \mathrm{C}$ against several changes of water and then lyophilized.

\section{Preparation of tryptic digest}

The thiol-alkylated, tritiated enzyme adduct was suspended in about $1 \mathrm{ml}$ of $\mathrm{H}_{2} \mathrm{O}$ containing $10 \%(\mathrm{v} / \mathrm{v})$ 1-propanol and the $\mathrm{pH}$ of the mixture was adjusted to 8.5 with triethylamine. TPCK-trypin $(40: 1 \mathrm{~mol}$ ratio, enzyme subunit/trypsin) was then added and digestion was carried out for $4 \mathrm{~h}$ at $37^{\circ} \mathrm{C}$; the $\mathrm{pH}$ of the reaction mixture was maintained at 8.5 throughout this period of time. The reaction was terminated by adding $0.1 \mathrm{ml}$ of glacial acetic acid followed by immediate lyophilization of the peptide digest to dryness.

\section{Peptide mapping and purification procedures}

The lyophilized peptide digest was dissolved in $1 \mathrm{ml}$ of $\mathrm{H}_{2} \mathrm{O}$ containing $0.1 \%(\mathrm{v} / \mathrm{v})$ TFA and the solution filtered. Analytical peptide maps were obtained by injecting 3-5 nmol of the digest onto a Waters Novapak $\mathrm{C}_{18}$ HPLC column $(3.9 \mathrm{~mm} \times 15 \mathrm{~cm})$ at room temperature equilibrated with $0.1 \%$ (v/v) TFA. Peptides were separated and eluted by use of the following solvent systems in sequence: isocratic solvent flow for 0-5 min with $0.1 \%(\mathrm{v} / \mathrm{v})$ TFA in $\mathrm{H}_{2} \mathrm{O} ; 5-10$ min linear gradient of acetonitrile $(0-10 \%, \mathrm{v} / \mathrm{v})$ in $0.1 \%$ TFA; maintenance of the isocratic system for $10-15 \mathrm{~min}$; variable linear gradients (as indicated, respectively, in parentheses) of acetonitrile in $0.1 \%$ TFA for 15-25 min (10-20\%), $25-45 \min (20-30 \%)$, and $45-65 \min (30-35 \%)$. The 
flow rate $=1 \mathrm{ml} / \mathrm{min}$. Preparative amounts of digests ( $>20 \mathrm{nmol}$ ) were handled in the same manner. Fractions $(1 \mathrm{ml})$ were collected and the presence of any radiolabeled peptide was determined by analyzing all fractions by liquid scintillation counting.

Those fractions containing the bulk of the radioactivity were pooled and further purified by HPLC using a linear gradient of $5-44 \%(\mathrm{v} / \mathrm{v})$ acetonitrile in $1 \mathrm{mM}$ sodium/potassium phosphate buffer ( $\mathrm{pH} \mathrm{6.2)} \mathrm{for} 39$ $\min (1.0 \mathrm{ml} / \mathrm{min})$ on a Waters Novapak $\mathrm{C}_{18}$ analytical column. The pure peptide so obtained was desalted by the TFA/acetonitrile solvent systems described above for the separation and elution of peptides.

\section{Amino acid analyses}

The purified, radioactive pyridoxyllysine peptide was subjected to amino acid analyses by HPLC as PTCamino acid derivatives using the Waters Pico-Tag column $(3.9 \mathrm{~mm} \times 15 \mathrm{~cm})$ and procedure [16]. Samples were hydrolyzed at $110^{\circ} \mathrm{C}$ for 24 and $96 \mathrm{~h}$, respectively, with $6 \mathrm{M} \mathrm{HCl}$ containing $1 \%(\mathrm{v} / \mathrm{v})$ phenol. The amino acids in the hydrolyzed samples were derivatized with phenylisothiocyanate and the corresponding PTC-derivatives were detected after separation at $254 \mathrm{~nm}$ [16].

The thiol-alkylated, tritiated enzyme adduct was hydrolyzed with $6 \mathrm{M} \mathrm{HCl}$ at $110^{\circ} \mathrm{C}$ for $24 \mathrm{~h}$ and the hydrolysate analyzed for $\varepsilon-N$-pyridoxyllysine on a Beckman Model $120 \mathrm{C}$ automated amino acid analyzer using a small column $(0.9 \times 18 \mathrm{~cm})$ of Aminex-A5 resin. The elution buffers were $0.36 \mathrm{M}$ sodium citrate $(\mathrm{pH} 4.53)$ $(0-75 \mathrm{~min})$ followed by $1.0 \mathrm{M}$ sodium citrate ( $\mathrm{pH} 6.4$ ) (75-130 min). Under these conditions, $\varepsilon-N$-pyridoxyllysine was well-resolved, eluting between histidine and arginine.

\section{Peptide sequencing}

The purified, radioactive pyridoxyllysine peptide ( 5 nmol) was concentrated to dryness and sequenced manually by the thin-film and the partitioning method described by Tarr [17]. The PTH-amino acid derivatives were separated isocratically on an Altex Ultrasphere ODS HPLC column $(4.6 \mathrm{~mm} \times 25 \mathrm{~cm})$ with a solvent system consisting of $55 \%(\mathrm{v} / \mathrm{v}) 0.01 \mathrm{M}$ sodium acetate

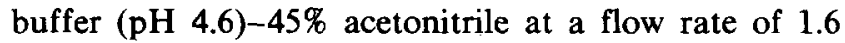
$\mathrm{ml} / \mathrm{min}$. The column was jacketed and maintained at $40^{\circ} \mathrm{C}$; the effluent was monitored at $254 \mathrm{~nm}$. Tyrosine and alanine, which are not resolved by this system, were separated and identified by a modification of the gradient-PTH-amino acid separation procedure of Hunkapiller and Hood [18] on an IBM cyanopropyl analytical HPLC column $(4.6 \mathrm{~mm} \times 25 \mathrm{~cm})$.

\section{C-Terminal amino acid determination of the ligase}

For this purpose, the procedure of Hayashi [19] was followed. Digestion was carried out in $0.1 \mathrm{M}$ pyridineacetate buffer ( $\mathrm{pH} \mathrm{5.5)}$ at room temperature using a mol ratio of carboxypeptidase $\mathrm{Y} /$ ligase of $1: 40$. At various time intervals, aliquots of the digestion mixture were removed, immediately frozen, and then lyophilized to dryness. The amino acids released were converted to their corresponding PTC derivatives and identified by HPLC using the Waters Pico-Tag column as indicated earlier.

\section{Results}

Identification of $\varepsilon$ - $N$-pyridoxyllysine and stoichiometry of pyridoxal phosphate binding

Acid hydrolysates of the $\mathrm{NaB}^{3} \mathrm{H}_{4}$-reduced hololigase were first examined by thin-layer chromatography on Avicel plates; samples were cochromatographed with authentic $\varepsilon-N$-pyridoxyllysine. A single, UV-fluorescent spot, coincident with the reference compound, was uniformly seen which had an $R_{\mathrm{F}}$ value of $0.20,0.32$ and 0.13 , respectively, in the following solvent systems: $n$ butanol/propionic acid/water (8:4:5); $n$-butanol/ pyridine/acetic acid/water (30:20:6:24); water/ methanol/ethanol/ benzene/pyridine/ dioxane (25: $25: 10: 10: 10: 10$ ). Furthermore, the UV-fluorescent spot present in the hydrolysate contained essentially all the radioactivity applied to the plate and the spot corresponding to the synthetic reference compound gave the typical color response when sprayed with ninhydrin. $\varepsilon-N$-Pyridoxyllysine was also detected and identified in hydrolysates of the tritiated enzyme adduct with the use of the amino acid analyzer, as described under Materials and Methods. The radioactive and the reference compound eluted with the same retention time, appearing between histidine and arginine.

The stoichiometry of binding of pyridoxal phosphate was determined by two procedures. The amino acid analyzer with a short column of Aminex-A5 resin, as described under Materials and Methods, was used first. Comparison of the ninhydrin color yield for the isolated $\varepsilon-N$-pyridoxyllysine with that of the standard compound gave a value of $0.94 \mathrm{~mol}$ of pyridoxal phosphate bound per mol of enzyme subunit. The method of Ulevitch and Kallen [20] was also applied. A sample of the pure enzyme in $50 \mathrm{mM}$ Hepes buffer ( $\mathrm{pH} 7.5)$, containing 1 mM EDTA plus $25 \mathrm{mM} \mathrm{Na} \mathrm{SO}_{4}$, was treated with 0.2 $\mathrm{M}$ cysteine $\cdot \mathrm{HCl}$ for $5 \mathrm{~min}$ at room temperature followed by heat denaturation for $2 \mathrm{~min}$ in a boiling water bath. The mixture was then cooled and the precipitate of protein removed by centrifugation. The concentration of thiazolidine derivative present in the supernatant fluid was determined spectrophotometrically at $335 \mathrm{~nm}$, using a value of $5580 \mathrm{M}^{-1} \cdot \mathrm{cm}^{-1}$ for its molar absorptivity at $\mathrm{pH} 7.5$; a value of $0.81 \mathrm{~mol}$ of pyridoxal phosphate per mol of enzyme subunit was obtained. Together, these results show that E. coli 2-amino-3ketobutyrate contains $1 \mathrm{~mol}$ of coenzyme per subunit. 


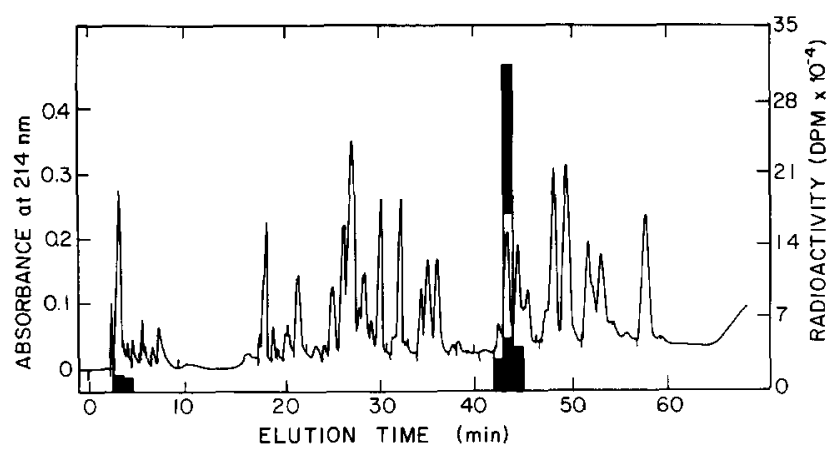

Fig. 1. Tryptic peptide profile of $E$. coli 2-amino-3-ketobutyrate ligase. The thiol-alkylated, $\mathrm{NaB}^{3} \mathrm{H}_{4}$-reduced ligase was digested with TPCK-trypsin and the digest fractionated by HPLC as described under Materials and Methods. The solid histograms indicate the amount of radioactivity found in each peak.

Tryptic peptide map of the thiol-alkylated, $\mathrm{NaB}^{3} \mathrm{H}_{4}$-reduced hololigase

The alkylated, tritiated holoenzyme was subjected to proteolytic digestion with TPCK-trypsin as described under Materials and Methods. A representative HPLC peptide map of such a digest is shown in Fig. 1. Amino acid analyses of native $E$. coli 2-amino-3-ketobutyrate ligase showed that the molecule contains 16 lysine and 26 arginine residues per enzyme subunit [12]. Of the 43 possible tryptic peptides, therefore, some $26-28$ are seen as $214 \mathrm{~nm}$ absorbing peaks; the difference is most likely due to the presence of several overlapping peptides. In several runs, however, the peak eluting at 43.8 min was routinely found to contain $80 \%$ or more of the applied radioactivity, with smaller amounts present in the fraction immediately preceding and following this peak. The remainder $(\sim 7 \%)$ of the applied radioactivity eluted early in the chromatographic run. Overall, 90 to $95 \%$ of the applied radioactivity was routinely accounted for in such separations.

\section{Purification and sequence determination of the pyridoxyl- lysine peptide}

The radioactive peak eluting at $43.8 \mathrm{~min}$ in Fig. 1 was purified on a Novapak $\mathrm{C}_{18}$ column (Waters Associates) using a linear gradient of acetonitrile in $1 \mathrm{mM}$ sodium/potassium phosphate buffer (pH 6.2) as described under 'Methods'. Fig. 2 shows the elution profile obtained. The peak eluting at 25 min contained virtually all the radioactivity eluted from the column. Overall, the recovery of this peptide following purification and subsequent desalting in the TFA/acetonitrile system was $70 \%$.

Table I shows the amino acid composition of this purified radioactive peptide. We found that $1 \%$ phenol must be present in the hydrolysis mixture; if not included, the one tyrosine residue was almost completely lost. Table I also shows that a longer hydrolysis time $(96 \mathrm{~h})$ was necessary for complete recovery of

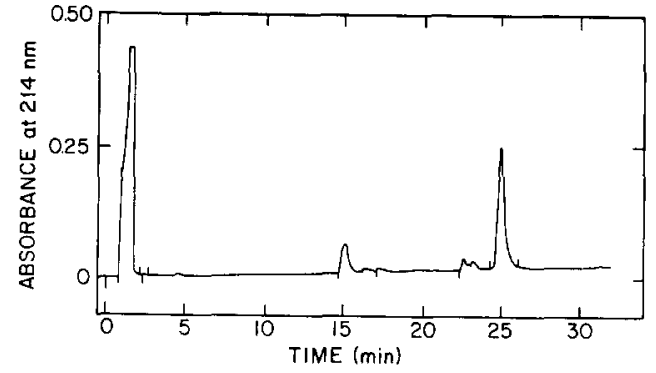

Fig. 2. Rechromatography of the primary radioactive peptide isolated from a tryptic digest of $E$. coli 2-amino-3-ketobutyrate ligase. The radioactive peak eluting at $43.8 \mathrm{~min}$ in Fig. 1 was chromatographed a second time in $1 \mathrm{mM}$ sodium/potassium phosphate buffer ( $\mathrm{pH}$ 6.2) versus acetonitrile as described under Materials and Methods. The peptide eluting at $25 \mathrm{~min}$ contained all the radioactivity.

isoleucine. Essentially all the radioactivity in these HPLC-amino acid analyses was present in one fraction (eluting after lysine) which was identified as $\varepsilon-N$ pyridoxyllysine by comparison with the synthetic reference compound.

The results obtained when the amino acid sequence of this peptide was determined were entirely consistent with the amino acid composition data given in Table I. The PTH-amino acid derivative detected in cycle 10 of the sequence determination had the same elution time as PTH- $\varepsilon-N$-pyridoxyllysine and contained $>90 \%$ of the radioactivity present in the peptide. The 23-amino acid peptide that had been isolated was found to have this primary sequence: Val-Asp-Ile-Ile-Thr-Gly-ThrLeu-Gly-(PL-Lys)-Ala-Leu-Gly-Gly-Ala-Ser-Gly-GlyTyr-Thr-Ala-Ala-Arg (where PL-Lys = pyridoxyllysine)

\section{TABLE I}

Amino acid composition of the pyridoxyllysine peptide of $E$. coli 2amino-3-ketobutyrate ligase

\begin{tabular}{|c|c|c|c|c|}
\hline \multirow[t]{3}{*}{ Amino acid } & \multicolumn{4}{|c|}{ Hydrolysis time } \\
\hline & \multicolumn{2}{|l|}{$24 \mathrm{~h}$} & \multicolumn{2}{|l|}{$96 \mathrm{~h}$} \\
\hline & $\mathrm{nmol}$ & $\begin{array}{l}\text { residue/ } \\
\text { peptide }^{\text {a }}\end{array}$ & $\mathrm{nmol}$ & $\begin{array}{l}\text { residue/ } \\
\text { peptide }^{\text {a }}\end{array}$ \\
\hline Asp & 3.3 & $0.9(1)^{b}$ & 3.0 & $0.9(1)^{b}$ \\
\hline Ser & 3.4 & $0.9(1)$ & 3.5 & $1.0(1)$ \\
\hline Gly & 20.8 & $5.8(6)$ & 21.6 & $6.2(6)$ \\
\hline Arg & 3.6 & $1.0(1)$ & 3.5 & $1.0(1)$ \\
\hline Thr & 9.8 & $2.7(3)$ & 8.0 & $2.3(3)$ \\
\hline Ala & 14.7 & $4.1(4)$ & 14.0 & $4.0(4)$ \\
\hline Tyr & 3.9 & $1.1(1)$ & 3.8 & $1.1(1)$ \\
\hline Val & 3.9 & $1.1(1)$ & 4.0 & $1.1(1)$ \\
\hline Ile & 4.9 & $1.4(2)$ & 6.5 & $1.9(2)$ \\
\hline Leu & 7.9 & $2.2(2)$ & 7.6 & $2.2(2)$ \\
\hline PL-Lys ${ }^{c}$ & 3.1 & $0.9(1)$ & 2.8 & $0.8(1)$ \\
\hline $\operatorname{Trp}$ & n.d. ${ }^{d}$ & n.d. (0) & n.d. & n.d. (0) \\
\hline
\end{tabular}

All values are normalized to 1.0 arginine per peptide.

b The values in parentheses are the values found by sequence analysis.

c PL-Lys $=\varepsilon$ - $N$-pyridoxyllysine.

d n.d., not determined. 


\author{
E. coli 2-Amino-3-ketobutyrate ligase \\ 5-Aminolevulinate synthase \\ (chicken liver mitochondria)
}

$V-D-I-I-T-G-T-L-G-\stackrel{*}{K}-A-L-G-G-A-S-G-G-Y-T-A-A-R$

$D-I-I-S-G-T-L-G-K-A$

(* Lysine Residue in Azomethine

Linkage with Pyridoxal-5'-phosphate)

Fig. 3. Sequence homology of the pyridoxyllysine peptide from $E$. coli 2-amino-3-ketobutyrate ligase with a segment of the primary structure of 5-aminolevulinate synthase from chicken liver.

\section{C-Terminal amino acid determination of the native en-} zyme

The C-terminal end of $E$. coli 2-amino-3-ketobutyrate ligase was examined by digestion with carboxypeptidase $\mathrm{Y}$; alanine was most rapidly released followed in order by isoleucine, valine and glycine. A maximum of approx. $1 \mathrm{~mol}$ of alanine was found to be released per mol of enzyme subunit. Controls lacking either the carboxypeptidase or the ligase showed the presence of virtually no free amino acids. The data indicated that the $\mathrm{C}$-terminal amino acid sequence of this ligase is [. . Gly-Val-Ile-Ala-COOH].

\section{Discussion}

After we succeeded in developing a reproducible procedure for isolating pure 2-amino-3-ketobutyrate ligase in good yield (30-40 mg of enzyme per $100 \mathrm{~g}$ wet weight of cells) from extracts of $E$. coli, we first reported [12] that this enzyme has an apparent $M_{\mathrm{r}}$ of 84000 , consists of two identical subunits, has a fairly typical amino acid composition (a total of 387 amino acid residues per subunit), is strictly specific for glycine but effectively utilizes either acetyl-CoA or $n$-propionylCoA as substrate, has a $\mathrm{pH}$ optimum of 7.5 , and requires pyridoxal 5'-phosphate for activity. Many of these properties of the bacterial enzyme are similar to those found for 2-amino-3-ketobutyrate ligase from bovine liver mitochondria (the only other source from which the pure ligase has so far been obtained); the enzyme from these two sources differs in that the liver ligase consists of 270 amino acid residues per subunit (subunit $M_{\mathrm{r}}=28000$ ) which includes no half-cystine and no tryptophan residues [11], whereas the $E$. coli ligase contains six and two of these residues per subunit, respectively.

Beside the spectral and inhibition data reported earlier [12], the results presented here on the isolation and identification of $\varepsilon-N$-pyridoxyllysine clearly establish that the coenzyme of 2-amino-3-ketobutyrate ligase is bound to the enzyme as a Schiff base to the $\varepsilon$-amino group of a lysine residue, which is typical of pyridoxal phosphate-dependent enzymes generally [21-24]. Quantitative measurements with the $E$. coli ligase show that $1 \mathrm{~mol}$ of pyridoxal phosphate is bound/enzyme subunit; the same stoichiometry of binding was found for the bovine liver ligase [11].
Now that the coupled action of L-threonine dehydrogenase with 2-amino-3-ketobutyrate ligase, whereby Lthreonine is converted to glycine plus acetyl-CoA, is recognized as the major route for $\mathrm{L}$-threonine metabolism in both eukaryotes and prokaryotes, studies are in progress to establish structure-function interrelationships of each enzyme and to examine how they work together in concert. Efficient and possibly regulated handling of the unstable intermediate, 2-amino-3-ketobutyrate, must be involved, since spontaneous decarboxylation of this $\beta$-keto acid with liberation of aminoacetone is another metabolic alternative. LThreonine has been shown to be a precursor of the D-1-amino-2-propanol moiety of Vitamin B-12 [25,26] and the conversion of $\mathrm{L}$-threonine $\rightarrow$ aminoacetone $\rightarrow$ D-1-amino-2-propanol has been demonstrated with enzymes from $E$. coli $\mathrm{K}-12$ [27]. Whether such a route actually operates in corrinoid biosynthesis remains to be determined.

The results presented here on a short sequence at the C-terminus and of a 23-amino acid peptide within the molecule, together with the $\mathrm{N}$-terminus sequence reported earlier [12], fully confirm that the complete amino acid sequence of $E$. coli 2-amino-3-ketobutyrate ligase is correct as inferred by DNA sequencing [13]. More importantly, the work outlined here is the first step in delineating structure-function interrelationships of the $E$. coli ligase, giving the amino acid sequence around the catalytically essential pyridoxal phosphatebinding site. Although the partial or total amino acid sequence of several other pyridoxal phosphate-dependent enzymes have more recently been reported (see, for example, Refs. 28 and 29), the paper of Minchiotti et al. [30] on some 38 different enzymes is probably the latest general analysis of common amino acid characteristics around the pyridoxal phosphate-binding site. The most common features noted were that such peptides (a) are particularly rich in non-polar amino acids; (b) contain a hydroxylated amino acid residue or residues (serine and/or threonine) at a definite distance (three or four amino acid residues removed) on the $\mathrm{N}$-terminal side of the Schiff base-forming lysine residue; and (c) often have a histidine residue immediately adjacent to and on the amino side of the active-site lysine [31-34]. As can be seen for the amino acid sequence given in the first line of Fig. 3, many but not necessarily all of these features are evident around the active-site lysine of $E$. 
coli 2-amino-3-ketobutyrate ligase. This peptide contains a number of non-polar amino acid residues; it also has a threonine three residues removed on the $\mathrm{N}$-terminal side and a serine six residues away on the C-terminal side of the pyridoxyllysine. A histidine residue, however, is not present immediately adjacent on one or the other side of the active-site lysine nor is any lysine or arginine residue near this locus. Curiously, the sequence of the pyridoxal phosphate-binding peptide found in diaminopropionate ammonia-lyase from Salmonella typhimurium [29] is homologous with a number of residues on the C-terminal side of the active-site lysine in the peptide reported here.

In addition to such general similarities and differences, we uncovered a very interesting comparison with one specific pyridoxal phosphate-dependent enzyme. This enzyme is 5-aminolevulinate synthase which, in the first step for heme biosynthesis, catalyzes the condensation of succinyl-CoA with glycine. Borthwick et al. [35] recently reported the nucleotide sequence of a cDNA clone coding for the precursor of this synthase from which they deduced the complete primary structure of both the precursor and the mature enzyme. A careful analysis of these results shows that a 10 -amino acid stretch of the primary structure of 5-aminolevulinate synthase from chicken liver (residues 376-385 out of a total of 579 amino acid residues for the mature enzyme) has a very high degree of homology with the pyridoxyllysine peptide of $E$. coli 2-amino-3-ketobutyrate ligase (see Fig. 3). To the best of our knowledge, the peptide containing the pyridoxal phosphatebinding residue of 5-aminolevulinate synthase has not yet been reported; the degree of homology noted in Fig. 3 , however, would seem to suggest that residue 384 is a prime candidate for the active-site lysine in this synthase from chicken liver mitochondria. Interestingly, 5-aminolevulinate synthase and 2-amino-3-ketobutyrate ligase are both dimeric enzymes consisting of apparently identical subunits $[12,36]$ and both catalyze very similar reactions by presumably identical reaction mechanisms [12,37]; they differ, however, in that the one enzyme is strictly specific for succinyl-CoA and the other utilizes acetyl-CoA as substrate.

\section{Acknowledgement}

This investigation was supported by a research grant (DK-03718) from the National Institute of Diabetes and Digestive and Kidney Diseases, U.S. Public Health Service.

\section{References}

1 Dale, R.A. (1978) Biochim. Biophys. Acta 544, 496-503.

2 Bird, M.I. and Nunn, P.B. (1983) Biochem. J. 214, 687-694.
3 Komatsubara, S., Murata, K., Kisumi, M. and Chibata, I. (1978) J. Bacteriol. 135, 318-323.

4 Boylan, S.A. and Dekker, E.E. (1981) J. Biol. Chem. 256, 1809-1815.

5 Ravnikar, P.D. and Somerville, R.L. (1987) J. Bacteriol. 169, 2611-2617.

6 Bird, M.I., Nunn, P.B. and Lord, L.A.J. (1984) Biochim. Biophys. Acta 802, 229-236.

7 Newman, E.B., Kapoor, V. and Potter, R. (1976) J. Bacteriol. 126, 1245-1249.

8 McGilvray, D. and Morris, J.G. (1969) Biochem. J. 112, 657-671.

9 Bell, S.C. and Turner, J.M. (1976) Biochem. J. 156, 449-458.

10 Aoyama, Y. and Motokawa, Y. (1981) J. Biol. Chem. 256, 12367-12373.

11 Fubara, B., Eckenrode, F., Tressel, T. and Davis, L. (1986) J. Biol. Chem. 261, 12189-12196.

12 Mukherjee, J.J. and Dekker, E.E. (1987) J. Biol. Chem. 262, 14441-14447.

13 Aronson, B.D., Ravnikar, P.D. and Somerville, R.L. (1988) Nucleic Acids Res. 16, 3586.

14 Forrey, A.W., Oldsgaard, R.B., Nolan, C. and Fischer, E.H. (1971) Biochimie 53, 269-281.

15 Lowry, O.H., Rosebrough, N.J., Farr, A.L. and Randall, R.J. (1951) J. Biol. Chem. 193, 265-275.

16 Bidlingmeyer, B.A., Cohen, S.A. and Tarvin, T.L. (1984) J. Chromatogr. 336, 93-104.

17 Tarr, G.E. (1986) in Microcharacterization of Polypeptides: A Practical Manual (Shively, J.E., ed.), pp. 155-194, Humana Press, Clifton, NJ.

18 Hunkapiller, M.W. and Hood, L.E. (1983) Methods Enzymol. 91, 486-493.

19 Hayashi, R. (1976) Methods Enzymol. 45, 568-587.

20 Ulevitch, R.J. and Kallen, R.G. (1977) Biochemistry 16, 5342-5349.

21 Fischer, E.H., Kent, A.B., Snyder, E.R. and Krebs, E.G. (1958) J. Am. Chem. Soc. 80, 2906-2907.

22 Schirch, L.G. and Mason, M. (1963) J. Biol. Chem. 238, 1032-1037.

23 Morino, Y. and Snell, E.E. (1967) J. Biol. Chem. 242, 2800-2809.

24 Strausbauch, P.H. and Fischer, E.H. (1970) Biochemistry 9, 233-238.

25 Krasna, A.I., Rosenblum, C. and Sprinson, D.B. (1957) J. Biol. Chem. 225, 745-750.

26 Müller, G., Gross, R. and Siebke, G. (1971) Hoppe-Seyler's Z. Physiol. Chem. 352, 1720-1722.

27 Campbell, R.L. and Dekker, E.E. (1973) Biochem. Biophys. Res. Commun. 53, 432-438.

28 Tanizawa, K., Ohshima, A., Scheidegger, A., Inagaki, K., Tanaka, H. and Soda, K. (1988) Biochemistry 27, 1311-1316.

29 Nagasawa, T., Tanizawa, K., Satoda, T. and Yamada, H. (1988) J. Biol. Chem. 263, 958-964.

30 Minchiotti, L., Ronchi, S. and Rippa, M. (1981) Biochim. Biophys. Acta 657, 232-242.

31 Appelbaum, D., Sabo, D.L., Fischer, E.H. and Morris, D.R. (1975) Biochemistry 14, 3675-3681.

32 Sabo, D.L. and Fischer, E.H. (1974) Biochemistry 13, 670-676.

33 Fluri, R., Jackson, L.E., Lee, W.E. and Crawford, I.P. (1971) J. Biol. Chem. 246, 6620-6624.

34 Schirch, L. (1982) Advances Enzymol. 53, 83-112.

35 Borthwick, I.A., Srivastava, G., Day, A.R., Pirola, B.A., Snoswell, M.A., May, B.K. and Elliott, W.H. (1985) Eur. J. Biochem. 150, 481-484.

36 Whiting, M.J. and Granick, S. (1976) J. Biol. Chem. 251, 1340-1346.

37 Shemin, D. (1970) Naturwissenschaften 57, 185-190. 